\title{
Development of Video Media Learning Basic Techniques of Table Tennis
}

\author{
Samsuddin Siregar ${ }^{1, *}$ Rosmaini Hasibuan ${ }^{2}$ Muhammad Yan Ahady ${ }^{3}$ \\ ${ }^{1}$ Physical Education Health and Recreation, Faculty of Sport Science, Universitas Negeri Medan, Jalan William \\ Iskandar Psr.V, Medan, Indonesia \\ ${ }^{2}$ Sport Science, Faculty of Sport Science, Universitas Negeri Medan, Jalan William Iskandar Psr.V, Medan, \\ Indonesia \\ ${ }^{3}$ Physical Education Health and Recreation, Faculty of Sport Science, Universitas Negeri Medan, Jalan William \\ Iskandar Psr.V, Medan, Indonesia \\ ${ }^{*}$ Corresponding author. Email: samsuddinsiregar@unimed.ac.id
}

\begin{abstract}
This study has the aim of developing video media for online learning of table tennis game courses at the Faculty of Sports Science (FIK) State University of Medan. This research method is part of the Borg and Gall (2007) method through stages; preliminary study, development, planning, expert judgment. The research subjects were FIK students. Data were collected through observation and interviews from validation experts. The data were analyzed quantitatively with the Liker scale percentage. The results of research on video media seen from the aspect of video media design quality reached $92 \%$ (very good). Then viewed from the aspect of the quality of the content of the material reached $88 \%$ (good) and for the aspect of video media display quality reached $96 \%$ (very good). Thus, it can be stated that the video media developed is included in the appropriate criteria. Based on the results of the data analysis above, it can be concluded that the media developed in this study is suitable for use by physical education teachers and lecturers as a medium in learning basic table tennis techniques during online and offline learning.
\end{abstract}

Keywords: Learning, Table Tennis, Media.

\section{INTRODUCTION}

Table tennis is a compulsory subject to be studied by students studying in the health and recreation physical education study program, Medan State University. After students study this course, students are expected to have 4 competencies, namely understanding the nature of table tennis, being skilled in practicing various table tennis techniques, analyzing and developing various forms of table tennis practice, applying the nature of table tennis and various skills possessed in learning situations (Samsuddin Siregar, 2020). During the 2019 Corona Virus Disease outbreak, the leadership of the Medan State University advised all lecturers so that the learning process system with students could be carried out without face to face. This rule was made with the reason that there is no spread or transmission of Corona Virus Disease 2019 in the Medan State University. As a result of the change in the learning system, namely from face-to-face learning to online learning systems, making table tennis lecturers at the State University of Medan unable to provide effective materials, media, learning resources for students, so that it has an impact on the low achievement of student competence in tennis courses. table.

Based on the reality faced by the table tennis lecturers, the researchers developed a table tennis learning video media for the student level (Chanavirut et al., 2017). This media was developed and designed through an analysis of the student's table tennis learning needs, seen from the facilities and infrastructure, initial understanding, early movement ability, and psychology. Then the content of this video media will be presented in a more simple, systematic and interesting way so that it is easy for students to understand.

This media will be used by table tennis lecturers as media and learning resources in learning table tennis. And this video media can also be used by students as a source to understand various basic techniques in table tennis and as a source of independent practice (Samsuddin Siregar, 2008). So that through online 
learning this video can be used in learning by using various application media.

\section{LITERATURE}

Table tennis according to (Larry Hodges, 1996) is a game in which a small ball is hit back and forth on the table, until someone makes a mistake to earn a point. This opinion explains that for every mistake there must be points, the accumulated points obtained determine the victory of each player. Then (Mc.Afee Richard, 2009) also explains table tennis is a sport that requires a combination of explosive power of the feet and fine motor skills in the hands.

The position of this sport in the curriculum of Physical Education, Health and Recreation, State University of Medan is a compulsory subject that has a weight of 2 credits. The target of this course to be studied by undergraduate students is so that students have knowledge and skill competencies in every basic technique in the table tennis game, which later these competencies will become provisions that can be transmitted through the educational process to their students at school (Mülling et al., 2013). The basic techniques are drive, push, block, smash, hit, servis, halley volley, side slip shot, loop, flip, drop shot, lob dan chop (Mc.Afee Richard, 2009). Learning media is one of the important aspects for a lecturer to master in carrying out his duties, in order to provide quality learning services, both in practical learning and in classical learning (Pei Zhou, a $\uparrow$ Dongfeng Dang, a $\uparrow$ Qiong Wang, a Xiongwei Duan, a Manjun Xiao, a, b Qiang Tao, a Hua Tan, a Renqiang Yang, 2015). Related to the definition of learning model, (Briggs, 1977) explained that the media in learning is a physical means to transfer information, knowledge, such as; videos, books, and so on. Another opinion on the meaning of media according to (Asyhar, 2012) is anything that can convey or distribute messages from sources in a planned manner, so that a conducive learning environment occurs where the recipient can carry out the learning process efficiently and effectively.

\section{RESEARCH METHODS}

This research is development research. The type of research and development in this study uses a model (Borg, W.R. \& Gall, 2007) which consists of ten steps, namely research and information colecting, planning, preliminary from of product, preliminary field testing, main product revision, main field testing, operation product revision, operational field testing, revision product, and disemination. However, due to time and cost constraints, of the ten stages that were passed in this study, only the main product revision stage was passed. The subjects used in the study consisted of three experts, namely experts in media, experts in design and experts in table tennis. The instruments used in the study were questionnaires and interviews. The research was carried out from 04 June to 10 June 2021 at the Multipurpose Building, Faculty of Sports Science, State University of Medan, Jalan Willem Iskandar Pasar V Medan Estate, Medan, North Sumatra. This development research data is qualitative data and quantitative data.

\section{RESULT AND DISCUSSION}

This development research begins with a needs analysis, the aim is to find out the problems and alternative solutions to overcome the existing problems. As for the aspects analyzed in the table tennis learning process that has been carried out so far, namely aspects of the student's ability to play table tennis, facilities and infrastructure, and aspects of student interest. The following graph illustrates the classification of students' abilities in playing table tennis.

\section{Student Skill Classification}

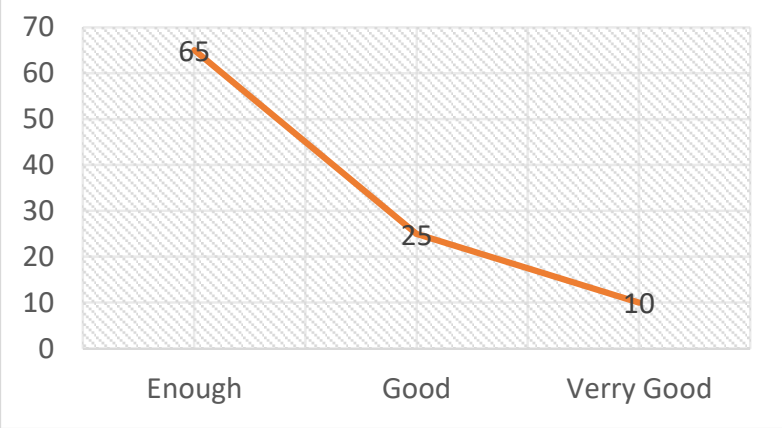

Figure 1. Classification of Students' Ability in Playing Table Tennis

The graphic description above describes students who have not been able to perform various basic techniques in the table tennis game as much as $65 \%$, good category as much as $35 \%$ and very good only $10 \%$. This classification can be understood that students need to obtain online learning methods and media that can improve their abilities, for that lecturers must be able to provide table tennis learning with effective media, methods, and materials. Then the facilities and infrastructure owned by students and lecturers are adequate, there are bets, table tennis courts and classes for learning.

Based on the findings of the analysis above, table tennis learning media was developed, which can be used as a learning resource and modeling for students. The following screen video was developed and can also be seen

at:https://drive.google.com/file/d/1tBYwn9YXt_wyQcS8JnWIpWq-G7O_cGj/view?usp=sharing. 

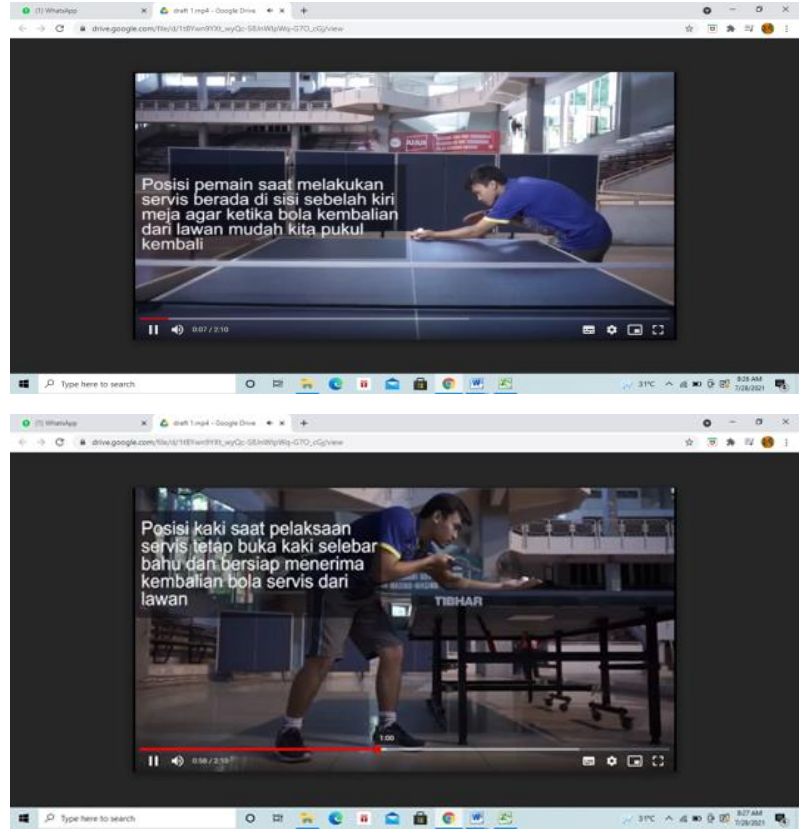

Figure 2. Screen Developed Video Media

The development of this media goes through 5 stages, namely:

- Preparation and coordination stage

- $\quad$ Recording stage

- $\quad$ Editing and design stage I

- Revision stage

- $\quad$ Editing and design stage II

- Final

The final media is the media that will be tested by experts to be evaluated and given advice on the developed media, so that it is better or the results are more perfect. There are 3 experts involved in this evaluation process, namely table tennis experts, learning media experts and video design experts. The experts were given a questionnaire as a measurable instrument used to evaluate the developed media. The following is a graph of the results of the expert's evaluation of the developed media.

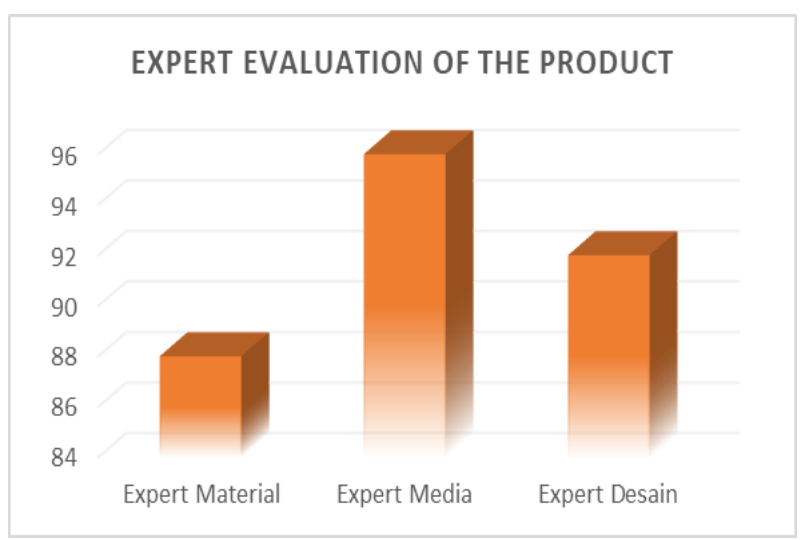

Figure 3. Results of Expert Evaluation of Products
The table above explains that the experts have provided an evaluation of the developed media. It can be seen from the table that the material expert gave a score of 88 or good, the media expert gave a score of 96 or very good for the developed media and the design expert gave a score of 92 or very good. The results of the expert's assessment explained that the media developed was suitable to be used as a table tennis learning media for students whose skills were still beginners. The media is very easy to learn, because it is presented in an attractive way, easy to understand because the video is equipped with a story board text that can be read. Good media is media that is easy to understand according to the characteristics of the person (Muhammad Ramli, 2021). Then the video is also equipped with audio whose language is very easy to understand.

\section{CONCLUSION}

Based on the results of the research that has been described previously, it can be concluded that the video media for learning basic table tennis techniques is appropriate for use in learning table tennis at the beginner level. For this reason, teachers and lecturers can use this video both online and in person in learning table tennis.

\section{REFERENCES}

[1] Asyhar, R. (2012). Kreatif Mengembangkan Media. Gaung Persada (GP) Press.

[2] Borg, W.R. \& Gall, M. D. G. (2007). Educational Research: An Introduction, Eighth Edition. Longman,Inc,

[3] Briggs, L. (1977). Instructional Design, Educational Technology. Englewood Cliffs.

[4] Chanavirut, R., Udompanich, N., Udom, P., Yonglitthipagon, P., Donpunha, W., Nakmareong, S., \& Yamauchi, J. (2017). The effects of strengthening exercises for wrist flexors and extensors on muscle strength and counter-stroke performance in amateur table tennis players. Journal of Bodywork and Movement Therapies, 21(4), 1033-1036.

https://doi.org/10.1016/j.jbmt.2017.02.002

[5] Larry Hodges. (1996). Table Tennis;Step to Succes. PT.RajaGrafindo Persada.

[6] Mc.Afee Richard. (2009). Table Tennis : Steps To Success. Human Kinetics Inc.

[7] Muhammad Ramli. (2021). Media dan Teknologi Pembelajaran. IAIN Antasari Press. http://idr.uinantasari.ac.id/10306/1/Buku Utuh Media Dan Teknologi Pembelajar-M.Ramli.pdf

[8] Mülling, K., Kober, J., Kroemer, O., \& Peters, J. (2013). Learning to select and generalize striking 
movements in robot table tennis. International Journal of Robotics Research. https://doi.org/10.1177/0278364912472380

[9] Pei Zhou, a $\uparrow$ Dongfeng Dang, a $\uparrow$ Qiong Wang, a Xiongwei Duan, a Manjun Xiao, a, b Qiang Tao, a Hua Tan, a Renqiang Yang, b W. Z. (2015). Materials Chemistry A. Journal of Materials Chemistry

https://doi.org/10.1002/14651858.CD012707

[10] Samsuddin Siregar. (2008). Perbedaan pengaruh metode mengajar dan kemampuan gerak terhadap keterampilan teknik dasar bermain bolavoli [Universitas Sebelas Maret]. https://core.ac.uk/download/pdf/16506878.pdf

[11] Samsuddin Siregar. (2020). Efektivitas Model Pembelajaran Berbasis Permainan Dalam Meningkatkan Keterampilan Forehanddrivemahasiswa. Jurnal Ilmu Keolahragaan, $\quad$ 19(1), 54-62. https://doi.org/https://doi.org/10.24114/jik.v19i1.18 455 